\title{
Molecular epidemiology of helminth diseases of the humpback grouper, Cromileptes altivelis, as a pattern for mapping fish diseases in the Sunda Strait, Indonesia
}

\author{
Sri Subekti1 ${ }^{\mathbb{D}}$, Muhammad Kholiqul Amiin² ${ }^{\mathbb{D}}$, Hervina Benazir Ardiyanti² (D), Muhammad Aiman Yudarana² \\ Ivan Achmadi2 (i) and Rizhar Eman Karunia Akbar $^{2}$ (D) \\ 1. Department of Marine, Faculty of Fisheries and Marine, Universitas Airlangga, Surabaya, Indonesia; 2. Department of \\ Biotechnology Fisheries and Marine, Universitas Airlangga, Mulyorejo, Surabaya 60115, East Java, Indonesia. \\ Corresponding author: Muhammad Kholiqul Amiin, e-mail: kholiqamiin7@gmail.com \\ Co-authors: SS: ssbendryman@yahoo.com, HBA: hervinabenazir@gmail.com, MAY: aimanyudarana@gmail.com, \\ IA: ivanachmadi7@gmail.com, and REKA: abe.rizhar@gmail.com \\ Received: 17-09-2020, Accepted: 12-04-2021, Published online: 27-05-2021
}

doi: www.doi.org/10.14202/vetworld.2021.1324-1329 How to cite this article: SubektiS, Amiin MK, Ardiyanti HB, Yudarana MA, Achmadi I, Akbar REK (2021) Molecular epidemiology of helminth diseases of the humpback grouper, Cromileptes altivelis, as a pattern for mapping fish diseases in the Sunda Strait, Indonesia, Veterinary World, 14(5): 1324-1329.

\begin{abstract}
Background and Aim: Neobenedenia girellae and Haliotrema epinepheli are important but neglected helminth parasites of marine fish. The humpback grouper, the most relevant definitive host, harbors several Neobenedenia and Haliotrema spp. simultaneously on body surfaces and gills. These species can be distinguished morphologically This study aimed to identify Neobenedenia and Haliotrema spp. infestations in monogenean humpback grouper by multiplex polymerase chain reaction method, which seems to be widely distributed in the study area. Data can be used as a basis for mapping disease patterns in Strait waters.
\end{abstract}

Materials and Methods: Eighty humpback groupers (Cromileptes altivelis) were collected from eight different areas in the Sunda Strait and examined using scrapings from body surfaces and gill lamellae followed by multiplex PCR for identification.

Results: Parasites on body surfaces were recovered from 49 fish (61.2\%) and were found on gill lamellae in 72 fish (90\%) by microscopic examination. Endoparasites were absent. Ectoparasites identified included, N. girellae, Neobenedenia melleni eggs, Neobenedenia pasifica, Neobenedenia longiprostata, Haliotrema eukurodai, H. kurodai, Haliotrema leporinus, Haliotrema dongshaense, Haliotrema angelopterum, Haliotrema aurigae, Haliotrema scyphovagina, and H. epinepheli.

Conclusion: The distribution of trematode disease in humpback grouper in Sunda Strait waters was revealed. All parasites were from genera, Neobenedenia and Haliotrema. Risks associated with these parasites should not be overlooked. Prevention and control programs need to be extended to other marine fish. Humpback grouper should be dewormed more frequently.

Keywords: humpback grouper, multiplex polymerize chain reaction, worm disease.

\section{Introduction}

Humpback groupers are an important resource in Indonesian waters. This species has substantial marketing potential, especially for export. Humpback groupers were included in the 20 major Indonesian fish exports in 2017. Farmed fish are exported to many countries, including Japan, Taiwan, Malaysia, the United States, and several European nations [1].

However, parasites remain an unresolved problem for the successful cultivation of the species. Factors that may influence parasite incidence in marine aquaculture are density of fish, environmental conditions and water quality (temperature, salinity, and $\mathrm{pH}$ ), fish handling, nutrition, feed resources, diet, and parasite/host relationships [2]. High stocking density encourages the spread of ectoparasites by

Copyright: Subekti, et al. Open Access. This article is distributed under the terms of the Creative Commons Attribution 4.0 International License (http://creativecommons.org/licenses/ by/4.0/), which permits unrestricted use, distribution, and reproduction in any medium, provided you give appropriate credit to the original author(s) and the source, provide a link to the Creative Commons license, and indicate if changes were made. The Creative Commons Public Domain Dedication waiver (http:// creativecommons.org/publicdomain/zero/1.0/) applies to the data made available in this article, unless otherwise stated. direct transfer from fish to fish. Farmers who use trash fish caught locally as fodder for valuable species can transmit the parasite from the surrounding area to cultivated fish [3].

Epidemiological studies and molecular techniques can be used to control parasitic disease in humpback grouper. These methods assess incidence, distribution, and type of disease in a population. Epidemiological disease investigations begin when disease first arises. Subsequently, the study can focus on connecting site conditions, population risks, time, environmental characteristics, notable symptoms, and lesions (sores).

This study aimed to identify Neobenedenia and Haliotrema spp. infestations in monogenean humpback grouper by multiplex polymerase chain reaction method, which seems to be widely distributed in the study area. Data can be used as a basis for mapping disease patterns in Strait waters.

\section{Materials and Methods}

\section{Ethical approval}

Ethical approval was not required for this study; however, samples were collected as per standard sample collection procedure. 


\section{Study period and locations}

Sampling was conducted in May 2019, a total of 80 species of humpback grouper taken every day from eight locations floating net cages different in the waters of the Sunda Strait (four locations in Lampung Province and four sites in Banten Province): KJA A (KA) (5³1 '40.01 “LS10514' 54.60” E), KJA B (KB) (5'33 '43.36 “LS105'32' 50.90” E), KJA C (KC) (5’44 '9:32’ LS105'35 '36.93 “E), KJA D (KD) (5'29' 24.00” LS105'17 '12:24 “E), KJA E (KE) (6³8' 33.59” LS10534 '53.45 “E), KJA F (KF) (6¹2' 00:02” LS106²9 '43.40 “E), KJA G (KG) (5'55'36.36”' LS106 09 '07.81 “E), and KJA H (KH) (6॰16 '00.79 'LS106²8' 5:19 'BT) (Figure-1).

\section{Fish collection}

The number of fish samples (n) and biometrics are as follows: KJA A (KA) $(146.2 \mathrm{~g}, 22.55 \mathrm{~cm}$, $\mathrm{n}=10)$; KJA B (KB) $(127.8,21.35 \mathrm{~cm}, \mathrm{n}=10)$; KJA $\mathrm{C}(\mathrm{KC})(89.5 \mathrm{~g}, 19.05 \mathrm{~cm}, \mathrm{n}=10)$. KJA D (KD) (110.2 g, $20.8 \mathrm{~cm}, \mathrm{n}=10$ ); KJA E (KE) (193.9 g, $23.85 \mathrm{~cm}, \mathrm{n}=10)$; KJA F (KF) (160.4 g, $22.25 \mathrm{~cm}$, $\mathrm{n}=10)$; KJA G (KG) (166.5 g, $21.86 \mathrm{~cm}, \mathrm{n}=10)$; and KJA H (KH) (144.8 g, $21.2 \mathrm{~cm}, \mathrm{n}=10)$. Fish samples were taken to the Laboratory of the Fish Health and Environment Marine Culture Centre in Lampung Province, Indonesia, for examination and sampling of parasitic worms.

\section{DNA extraction and multiplex polymerase chain reaction (PCR)}

RNA extraction used TriSol solution (Kit IQ2000TM). Up to two pieces of scales, fins, or gills $(300 \mathrm{mg})$, were place in $1 \mathrm{~mL}$ of PBS $(1 \mathrm{~mL})$ and tissues disrupted with a tissue disruptor until well blended. Two hundred and fifty microliters of sample and $750 \mu \mathrm{L}$ of TriSol were mixed and centrifuged at $12,000 \mathrm{~g}$ for $5 \mathrm{~min}$ at $4^{\circ} \mathrm{C}$. The supernatant was then incubated for $5 \mathrm{~min}$. One hundred and fifty microliters chloroform was added, incubation continued for 2-3 min, and mixtures centrifuged at 12,000 $\mathrm{g}$ for $5 \mathrm{~min}$ at $4^{\circ} \mathrm{C}$. Three phases were obtained; RNA-se, interphase, and red phenol chloroform. The RNA phase was mixed with $225 \mathrm{~mL}$ of $100 \%$ ethanol, by inverting and incubated for 2-3 min. The mixture was then centrifuged at $2000 \mathrm{~g}$ for $5 \mathrm{~min}$ at $4^{\circ} \mathrm{C}$. As much as, $200 \mu \mathrm{L}$ supernatant was then placed into a new $1.5 \mathrm{~mL}$ microtube and isopropanol. The mixture was incubated for $30 \mathrm{~min}$ with inverting and the mixture was then centrifuged using back vortex at $2000 \mathrm{~g}$ for $5 \mathrm{~min}$ at $4^{\circ} \mathrm{C}$. The supernatant was then discarded and the process repeated 3 times. The final pellet was suspended in as much as $1.5 \mathrm{~mL} 70 \%$ ethanol, then centrifuged again at $2000 \mathrm{~g}$ for $5 \mathrm{~min}$ at $4^{\circ} \mathrm{C}$. The supernatant was removed and the pellet dried in the air for $5-10 \mathrm{~min}$. The dried pellet was dissolved in $200 \mu \mathrm{L}$ of $8 \mathrm{mM} \mathrm{NaOH}$. Pellet RNA was then ready for use or storage after centrifuging again at $12,000 \mathrm{~g}$ for $10 \mathrm{~min}$ at $4^{\circ} \mathrm{C}$. The supernatant was used to develop the whole DNA product.

DNA extraction used a Qiagen DNA Mini Kit (Germany) with the protocol for tissue. Extraction followed the manufacturer's instructions with some modifications. Primers used for multiplex PCR are shown in Table-1. Amplification reactions used a $50 \mu \mathrm{L}$ volume, containing $28 \mu \mathrm{L}$ Master Mix, $5 \mu \mathrm{L}$ primers, $1 \mu \mathrm{L}$ MM, $5 \mu \mathrm{L} 10 \times$ buff, $5 \mu \mathrm{L}$ dNTP, $2 \mu \mathrm{L} \mathrm{MgSO}_{4}$, $2 \mu \mathrm{L}$ Primer F, $2 \mu \mathrm{L}$ Primer R, $1 \mu \mathrm{L}$ KOD ver. 2, and

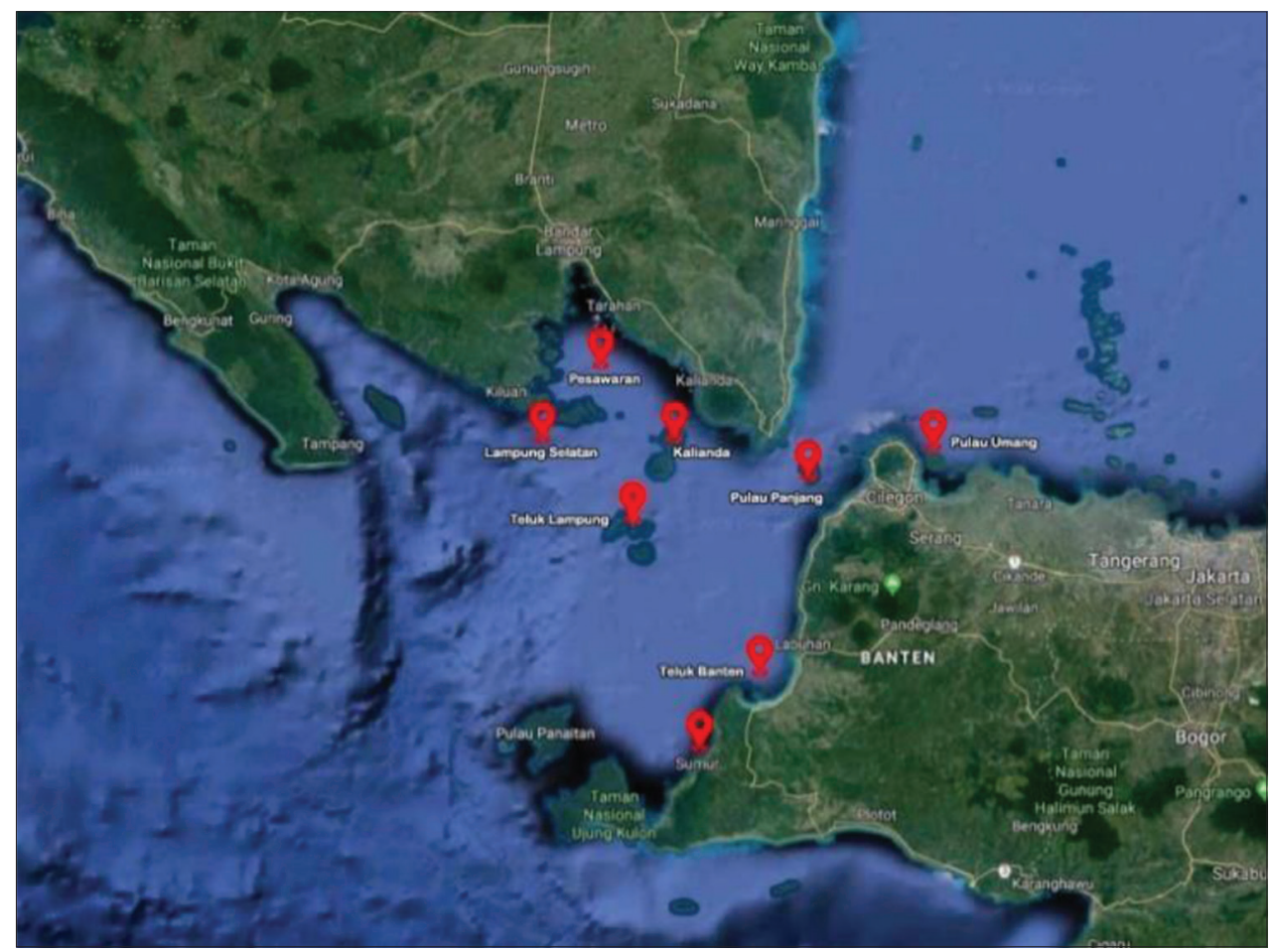

Figure-1: Map of Sunda Strait waters in Indonesia and its region, where humpback groupers samples were collected [Source: www.maps.google.com]. 
$5 \mu \mathrm{L}$ template DNA. PCR cycling conditions used one cycle of $2 \mathrm{~min}$ at $95^{\circ} \mathrm{C}$ for initial denaturation, $2 \mathrm{~min}$ primary denaturation at $93^{\circ} \mathrm{C}$; followed by 35 cycles of denaturing at $93^{\circ} \mathrm{C}$ for $1 \mathrm{~min}$, annealing at $51^{\circ} \mathrm{C}$ for $45 \mathrm{~s}$, and extension at $72^{\circ} \mathrm{C}$ for $2 \mathrm{~min}$ and a final extension at $72^{\circ} \mathrm{C}$ for $5 \mathrm{~min}$. Five microliters of each PCR product were analyzed by electrophoresis on 2\% agarose gels stained with Safe Stain. A 1000 bp molecular size ladder was run together with samples to determine fragment lengths. PCR products were visualized under ultraviolet light (UVI doc, England).

\section{Results}

Forty-nine of 80 examined fish (61.2\%) showed at least one parasite on scales and 72 of 80 fish (90\%) showed at least one parasite on gills. Neobenedenia girellae and Haliotrema epinepheli were observed in 80 samples. Parasites were used for multiplex PCR analysis. Amplification of 954, 824, and 710 bp fragments of target rRNA was observed in the KK 6 sample. The KK 12 sample displayed amplification of 955, 768, and 682 bp fragments; KK 17 exhibited amplification of 955 and $788 \mathrm{bp}$ fragments. The KK 46 sample displayed more DNA bands than other samples, with amplification of $955,822,703$, and $651 \mathrm{bp}$ fragments. The KK 53 sample showed amplification of 955 and $821 \mathrm{bp}$ fragments: KK 60 exhibited amplification of 954 and $836 \mathrm{bp}$ fragments. Only the $954 \mathrm{bp}$ fragment was amplified from KK 72. All samples indicated infestation with Neobenedenia spp. (Figure-2).

Positive results were also observed in gill samples. The KI 6 sample displayed 948 and 722 bp fragments; KI 12-948 and 728 bp fragments; KI 17-948, 834, and 728 bp fragments; and KI 46-948 and 760 bp fragments. The KI 53 sample showed amplification of $948,857,728$, and $647 \mathrm{bp}$ fragments, the most fragments among gill samples. The KI 60 sample exhibited amplification of 948,821 , and 722 bp fragments and KI 72-948, 860, 798, and 649 bp fragments. Seven samples (KI 6, 12, 17, 46, 53, 60, and 72) displayed the 948 bp and three samples (KI 12, 17, and 53) showed the $728 \mathrm{bp}$ fragments. All samples indicated infestation with Haliotrema spp. (Figure-3).

\section{Discussion}

A relatively high rate of parasitic infestation on scales and gills of $C$. altivelis was found in the study region of Sunda Strait, Indonesia. Several parasite species of monogenean trematode were identified, all in genera Neobenedenia and Haliotrema. Monogenean trematode parasites of humpback grouper are important because they decrease fish endurance that leads to further infestation or secondary infection by bacteria and viruses [4]. Parasitic worms infest fish through water that has been contaminated by affected fish in aquaculture and through direct contact with other fish infected by the worms. The spread of unhealthy fish has significant consequences, especially when stocking density is too high [5].

Data on the prevalence of parasitic infestation on fish scales can be used to inform control measures to minimize the risk of disease transmission among fish. The overall prevalence of parasites on scales and gills was $62.1 \%$ and $90 \%$, respectively, among 80 fish analyzed. This infection rate is greater than reported in waters of Chile (24\%) [6] and Mexico (53\%) [7], but less than in Japan (98.7\%) [8]. The rate of parasitic infestation in gills is greater than reported in Vietnam (2.2\%) [9] and Japan (62\%) [10], but less than Mexico (100\%) [11]. Among parasites detected, the trematode family, Capsilidae, contains two closely related genera, Neobenedenia and Benedenia. Species in these genera show different levels of pathogenicity that makes them the subjects of intensive epidemiological study [12].

Further, one parasite of the family Diplectanidae in the genus Haliotrema is of particular concern in epidemiological studies [12]. Accurate diagnoses of monogenean parasites provide key information for controlling infection of marine fish. Examination of scales and gills is not sufficiently accurate for epidemiological purposes because Neobenedenia and Benedenia spp. are similar, as are Haliotrema and Diplectanum spp. Likewise, immunological methods for copro-antigen detection and serum antibodies are not sufficiently specific to differentiate among pathogens at a species level [13]. To overcome these limitations, various molecular approaches, such as high-sensitivity multiplex PCR, have been developed $[13,14]$.

Use of multiplex PCR in our study showed $61.2 \%$ infestation rate with $N$. girellae and $90 \%$ with $H$. epinepheli of grouper from Sunda Strait waters. In regions outside Indonesia, different infestation rates with these species were reported in studies the multiplex PCR method. Kurniawan [15] and Subekti et al. [16] reported the rate of infestations of $N$. girellae as $44.44 \%$ and $56.67 \%$, respectively. The same researcher also reported an attack rate of $H$. epinepheli, respectively, at $27.78 \%$ and $26.67 \%$. Several environmental and socioecological factors are involved in the dispersal of $N$. girellae and $H$. epinepheli among hosts. These factors control the prevalence of

Table-1: Primers, targets, and sequences applied for multiplex PCR.

\begin{tabular}{llclc}
\hline Target species & Target gene & Primer designation & Sequences (5'-3') & Amplicon length (bp) \\
\hline Neobenedenia girellae & rRNA & ITS 1 & GATAGGCCCGTTCAGGTTGG & 768 bp \\
Haliotrema epinepheli & rRNA & ITS 2 & AGGCGTGGCTTCTTGACAAA & 821 bp \\
& & ITS 1 & CGCTTCAAGTCGTTCTGGGA & \\
\hline
\end{tabular}

$\mathrm{PCR}=$ Polymerase chain reaction 


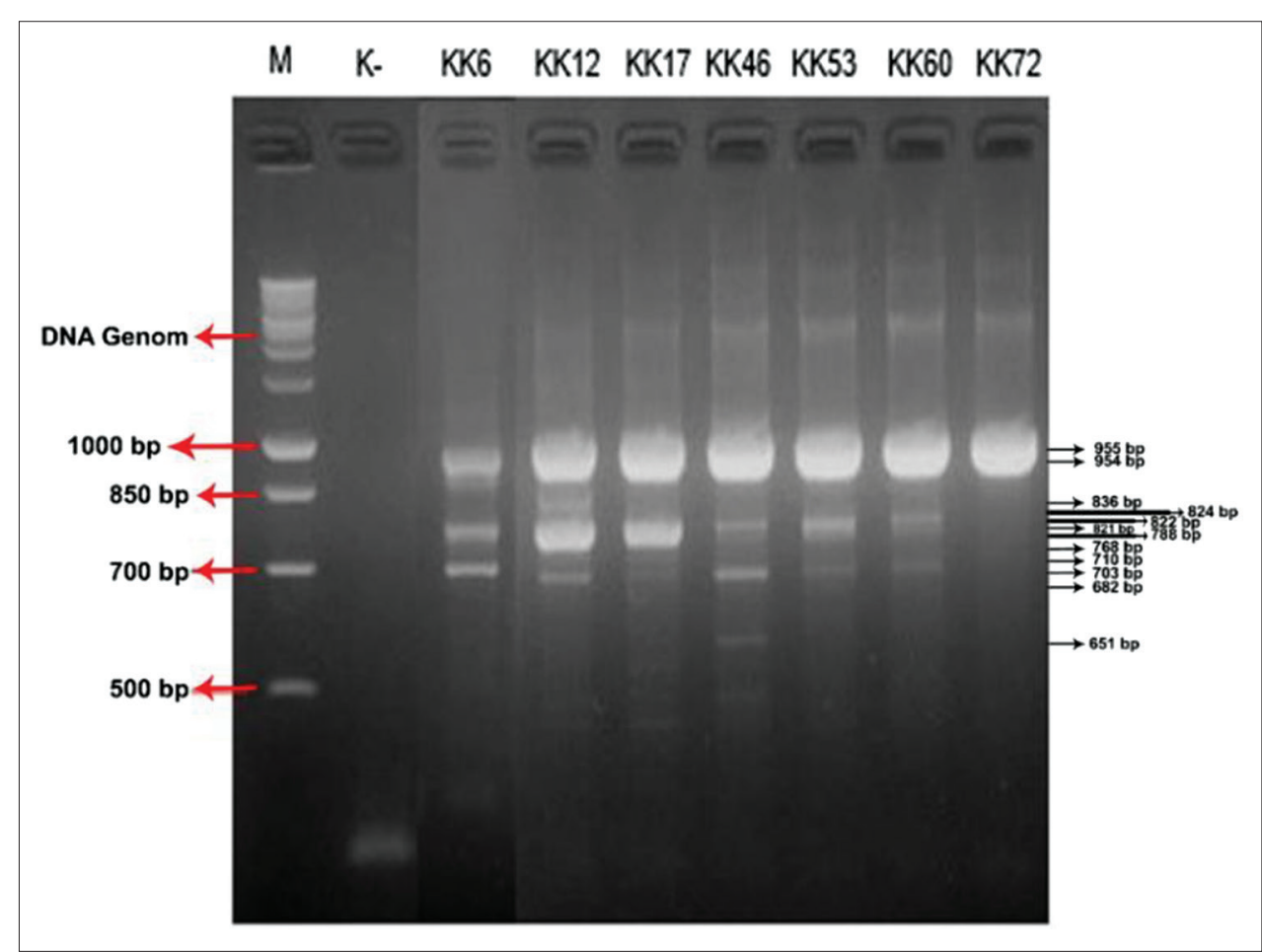

Figure-2: The results of PCR analysis on the scales of humpback grouper fish (Cromileptes altivelis). $\mathrm{M}$ is the $1000 \mathrm{bp}$ ladder. K- is negative control. Lanes KK 6, 12, 17, 46, 53, 60, and 72 are 650-955 bp PCR product representative of genera Neobenedenia.

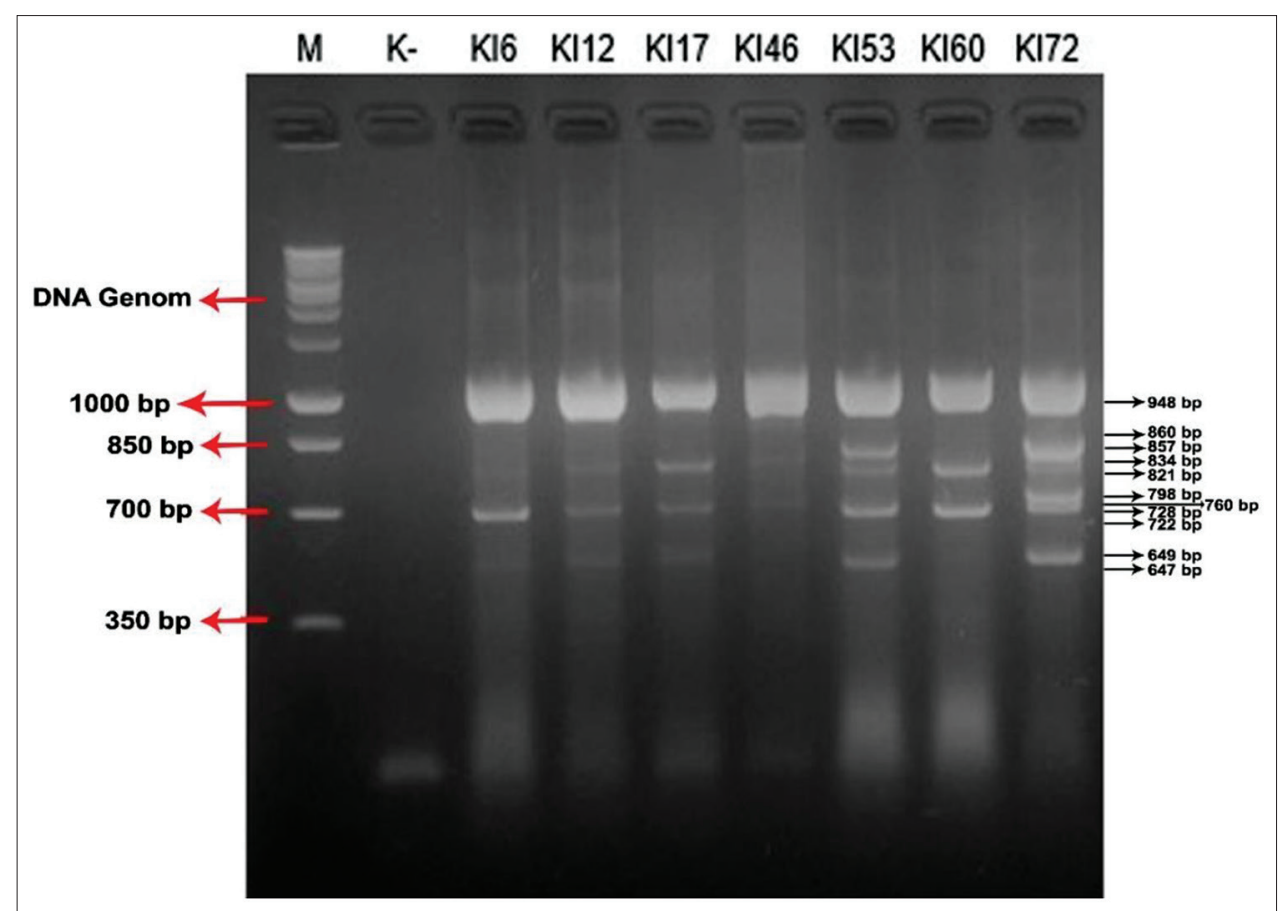

Figure-3: Gel electrophoresis of the polymerize chain reaction (PCR) products gills of humpback grouper fish (Cromileptes altivelis). M is the 1000 bp ladder. K- is negative control. Lanes KI 6, 12, 17, 46, 53, 60, and 72 are 647-948 bp PCR product representative of genera Haliotrema.

infestations. The incidence rate observed in fish may reflect a lack of control over fish and water quality, as well as low parasite levels; however, prevention of proliferation of monogenean parasites is still needed in the Sunda Strait. Trematode parasites develop rapidly. Eggs that hatch in water swim using cilia, called onchomiracidium, to find suitable hosts [2].
DNA bands amplified from rRNA from study fish display different amplicon lengths. Seven samples of scales exhibit amplification of 954-955 bp fragments. Parasites with 954-955 bp amplicon lengths can be classified as Neobenedenia melleni eggs [17]. $N$. melleni worm larvae show amplicon lengths of 651 and 703 bp [17]. The KK 46 sample displayed such 
amplicon lengths of 651 and 703 bp. Adult N. melleni worms appeared in the KK 46 samples with an amplicon length of 822 bp (Figure-3). These results are also consistent with previous research [17].

Other scale samples also showed different amplicon lengths. These results are consistent with Brazenor et al. [13], where $N$. girellae were associated with amplicon lengths of $682 \mathrm{bp}$ (KK 12), $710 \mathrm{bp}$ (KK 6), 768 bp (KK 12), 824 bp (KK 6), and 836 bp (KK 60) (Figure-2). In contrast, samples showing an amplicon length of $788 \mathrm{bp}$ (KK 17) (Figure-2) are classified as Neobenedenia pasifica. Other studies also found Neobenedenia longiprostata with an amplicon length of $821 \mathrm{bp} \mathrm{(KK} \mathrm{53)} \mathrm{[12].} \mathrm{Some} \mathrm{DNA} \mathrm{bands} \mathrm{found} \mathrm{sug-}$ gest a parasite dispersal pattern that involves the surface of a humpback grouper bodies. Multiplex PCR results show that $N$. girellae. $N$. melleni, $N$. pasifica, and $N$. longiprostata were also identified.

Multiplex PCR of gill specimens successfully amplified DNA, with bands indicating amplicon lengths of 948 bp (KI 6, KI 12, KI 17, KI 46, KI 53, KI 60 , and KI 72). This finding is consistent with a previous report [18] of amplicon lengths of Haliotrema spp. of 948-1000 bp. Further, Haliotrema spp. also display amplicon lengths of 720-730 bp [19], consistent with current results showing amplicon lengths of 722 bp (KI 6 and KI 60) and 728 bp (KI 12, KI 17, and KI 53). Further, several other DNA bands with different amplicon lengths were observed in samples KI 17 (834 bp), KI 46 (760 bp), KI 53 (647 and 857 bp), KI $60(821 \mathrm{bp})$, and KI $72(649,798$, and $860 \mathrm{bp})$ (Figure-3). Several parasitic species infest gills of humpback grouper in the waters of the Sunda Strait.

The targets of the current study were specimens of $H$. epinepheli. These worms were found and characterized by DNA bands with an amplicon length of $821 \mathrm{bp}$ in the KI 60 sample. Similar investigation reported amplicon lengths of 800-821 bp in $\mathrm{H}$. epinepheli [14]. Further, Sun et al. [14] also reported Haliotrema eukurodai, H. kurodai, Haliotrema leporinus, and Haliotrema dongshaense, displaying amplicon lengths of $834 \mathrm{bp}$ (KI 17), $760 \mathrm{bp}$. (KI 46), $857 \mathrm{bp}$ (KI 53), and 860 bp (KI 72), respectively. Multiplex PCR on seven samples of gill humpback grouper indicated only species of genus Haliotrema. H. epinepheli, which was targeted in this study, was identified.

\section{Conclusion}

Parasitic infestation by genera Neobenedenia and Haliotrema is endemic in humpback grouper in the Sunda Strait, Indonesia. The presence of ectoparasite infestations occurs because of poor fish management and uncontrolled water quality that fluctuates seasonally. The pattern of worm disease mapping in Sunda Strait waters is horizontal through contact with aquaculture media, such as floating net cages that have been contaminated by ectoparasitic worm larvae or by direct contact with other fish that are infected with ectoparasites. Differences in infestation rate within Sunda Strait waters depend on factors, such as definitive hosts. Additional study is required to determine the prevalence of parasites on all hosts in the study areas.

\section{Authors' Contributions}

MHK: Provided the research proposal and performed laboratory works. SS: Supervised the study and revised the manuscript. HBA: Prepared the study design. MAY, IA, and REKA: Collected the samples and managed the laboratory for the project. MKA: Drafted the manuscript. All authors read and approved the final manuscript.

\section{Acknowledgments}

The study was financially supported by the Research and Innovation Institute (LPI) Universitas Airlangga, Indonesia (Grant No. 384/UN3.14/ LT/2019/139).

\section{Competing Interests}

The authors declare that they have no competing interests.

\section{Publisher's Note}

Veterinary World remains neutral with regard to jurisdictional claims in published institutional affiliation.

\section{References}

1. Food and Agriculture Organization. (2018) World Review of Aquaculture Production. The State of World Fisheries and Aquaculture, Roma. p2-7.

2. Rohde, K. (2017) Ecology and Biogeography of Marine Parasites. Adv. Mar. Biol., 43(2): 1-86.

3. Clausen, J.H., Madsen, H., Thi Van, P., Dalsgaard, A. and Murrell, K.D. (2015) Integrated parasite management: Path to sustainable control of fishborne trematodes in aquaculture. Trends Parasitol., 31(1): 8-15.

4. Kordi, K.M. and Tamsil, A. (2011) Artificial Economical Sea Fish Hatchery, Yogyakarta. p22-25.

5. Riko, Y.A., Rosidah, R, and Herawati, T. (2012) Intensity and prevalence of ectoparasites in seawater fish in floating net cages in Cirata reservoir, Cianjur Regency, West Java. $J$. Fish., 3(4): 11.

6. Sepúlveda, F.A. and Gonzales, M.T. (2019) DNA barcoding evidence for the first recorded transmission of Neobenedenia spp. from wild fish species to Seriola lalandi cultured in an open recirculating system on the Coast of Northern Chile. Aquaculture, 501: 239-246.

7. Morales-Sernaa,F.N.,Chapa-López,M.,Martínez-Brown,J.M., Ibarra-Castro, L., Medina-Guerrero, R.M. and Fajer-Ávila, E.J. (2018) Efficacy of praziquantel and a combination anthel-

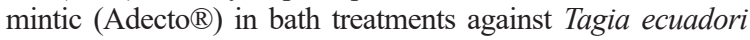
and Neobenedenia melleni (Monogenea), parasites of bullseye puffer fish. Aquaculture, 492: 361-368.

8. Hirazawa, N. (2019) Killing effects of various treatments on eggs of the skin-parasitic monogeneans Neobenedenia girellae and Benedenia seriolae. Aquaculture, 498(7): 285-288.

9. Dang, B.T., Levsen, A., Schander, C. and Bristow, G.A. (2010) Some Haliotrema (Monogenea: Dactylogyridae) from cultured grouper (Epinephelus spp.) with emphasis on the phylogenetic position of Haliotrema cromileptis. $J$. Parasitol. Res., 96(1): 30-39.

10. Nitta, M. and Nagasawa, K. (2016) A new species of Dactylogyrus (Monogenea: Dactylogyridae) parasitic on 
an endangered freshwater fish, Rhodeus atremius atremius, endemic to Japan. Parasitol. Int., 65(5): 483-487.

11. Soler-Jimenez, L.C., Morales-Serna, F.N. and Fajer-Avila, E.J. (2015) Rapid infection and proliferation of dactylogyrid monogeneans on gills of spotted rose snapper (Lutjanus guttatus) after transfer to a sea-cage. Vet. Parasitol., 75(9): 1-8.

12. Rückert, S., Klimpel, S. and Palm, H.W. (2010) Parasites of cultured and wild brown-marbled grouper Epinephelus fuscoguttatus (Forsskål, 1775) in Lampung Bay, Indonesia. Aquaculture, 41(8): 1158-1169.

13. Brazenor, A.K., Bertozzi, T., Miller, T.L., Whittington, I.D. and Hutson, K.S. (2018) DNA profiling reveals Neobenedenia girellae as the primary parasitic monogenean in global fisheries and aquaculture. Mol. Phylogenet. Evol., 129: 130-137.

14. Sun, Y., Li, M. and Yang, T. (2014) Studies on Lethrinitrema Lim and Justine, 2011 (Monogenea: Dactylogyridae), with the description of two new species, a key to the genus and a phylogenetic analysis based on rDNA sequences. Syst. Parasitol., 88(2): 119-139.
15. Kurniawan, A. (2015) Prevalence, Intensity and Identification of Ectoparasite Moleculars in Groupers in Pegametan bay Buleleng Regency, Yogyakarta, Thesis.

16. Subekti, S., Amin, M.K. and Kismiyati, K. (2019) Prevalence of trematodes on red snapper (Lutjanus argentimaculatus) in floating net cages at Lampung, Indonesia. Indian Vet. J., 96(2): 46-48.

17. Chen, J., Shi, Y.H., Lu, X.J. and Li, M.Y. (2010) Expressed Sequence Tags of cDNA Clones from Neobenedenia melleni.

18. Wu, X.Y., Xie, M.Q. and Li, A.X. (2006) The radiation of Haliotrema (Monogenea: Dactylogyridae: Ancyrocephalinae): Molecular evidence and explanation inferred from LSU rDNA sequences. Parasitology, 132(5): 659-668.

19. Yang, T., Kritsky, D.C., Sun, Y., Zhang, J., Shi, S. and Agrawal, N. (2006) Diplectanids infesting the gills of the barramundi Lates calcarifer (Bloch) (Perciformes: Centropomidae), with the proposal of Laticola n.g. (Monogenoidea: Diplectanidae). Syst. Parasitol., 63(2): 127-141.

$* * * * * * * *$ 